\title{
Gambia's Civil Service Pay Reforms: A solution on workforce satisfaction and performance
}

\author{
Bernard Nkala ${ }^{1}$, Alagi Sonko ${ }^{2}$ \\ ${ }^{1}$ Health Service Board, Department of Performance Improvement and Development, Zimbabwe \\ ${ }^{2}$ Department of Personnel management Office, Gambia \\ DOI: https://dx.doi.org/10.47772/IJRISS.2021.5322
}

\begin{abstract}
Following the implementation of the civil service pay reforms 2008 to 2015 in the Gambia, there are no clear practical indications as to improved motivation, satisfaction and enhanced performance of the Gambian civil servants. In light of this skepticism, the study assessed the effects of pay reforms on pay satisfaction and performance of the employees in the civil service. The objective of this study was to assess the pay satisfaction and performance levels and discuss the determinants of pay satisfaction in the civil service of the Gambia.
\end{abstract}

The study applied descriptive research format in dealing with quantitative and qualitative data. The study used structured survey questionnaire customized from the Pay Satisfaction Questionnaire method to collect primary data. Data was also collected using interview guide with key informants and conducted telephone interviews. Motivational theories by Abraham Maslowand Adams equity theory became the theoretical foundation of this research with the aid of a noperational framework developed by the researchers, to guide the direction of the research. The study sample consisted of randomly selected 60civil servants drawn from different ministries and line department from the Gambia in the capital city Banjul, based on purposeful sampling. Other regions and districts could not be included in this study due to resource constraints. Key informants interviewed were also exclusively limited to those cadres within urban centers given challenges associated with communication in the regions.

The study unearthed that satisfaction in the Gambian civil service has not improved following pay reforms. The poor reward system is the root cause of poor performance in the civil service as witnessed by cropping practices of attrition, indiscipline, corruption and absenteeism which still prevails in the civil service of the Gambia. The study recommends decompressing the pay structure and fostering on a participatory approach to decide issues to do with pay reforms. Lessons drawn from other African countries that experienced the same problem of pay reforms gives Gambia a chance to revisit its pay reform strategies with a view to deal with evident civil service poor performance. Study further recommends enhancement of monetary and non-monetary incentives to induce high motivation and satisfaction that shall translate to improved public sector performance. This study concludes that pay satisfaction is an important component of overall job satisfaction thus Gambia Personnel Management Office needs to embrace modern research approaches that will enhance satisfaction amongst civil service. Employee participation in pay issues is important as it helps to model effective pay reforms. The fit between incentive-specific reforms and the public reform process is therefore, a challenge that needs attention thus effort needs to be devoted to designing incentives aimed at changing the Gambia' civil service attitude and perceptions.

Key words: Pay Reform; Pay Structure, Pay Satisfaction; Gambia; Civil Service

\section{INTRODUCTION}

$\mathrm{I}_{\mathrm{p}}^{\mathrm{n}}$ social science, labour is one of the main factors of production, bought and sold at a price[1].Therefore, pay in any organization ought to be determined within the context of the economic and social forces that largely influence the demand and supply. The supply of labour in Gambia's civil service is a function of many determinants comprising of direct measurable monetary rewards such as pay, allowances and non-monetary features like job security and status and opportunities presented within service. The effects of low pay in the public sector spreads the vicious circle of under performance and high measures of dissatisfaction. Low pay my present performance related problems and translates into economic inefficiency resultant in under-utilisation of labour capacity[1]. The civil service of the Gambia from independence was sizable and had a reasonable degree of capacity, which lasted for a brief time span and thereafter the number of the workforce increased disproportionately owing to ad hoc recruitment. The growth of the civil service thus created a corresponding effect on the wage bill by raising it high and became unsustainable. The erosion of the wage value triggered negative effects in the service such as attrition, indiscipline, corruption and absenteeism, poor performance and loss of confidence in the civil service[1].

Poor public sector management, which renders so many development initiatives fruitless in many developing countries, has been acknowledged by the World Bank and other development partners. World Bank's policy on development cooperation with the third world, from the mid to the late 20th century, focus more on public sector reform to strengthen the institutions and capacity development[4] not excluding the Gambia. The Asian tigers were hailed by the World Bank in the 90s, for sound policy options that led to the progress of their societies [5][6]. The Gambia Government with support from the development partners initiated a series of civil service reform programmes in two phases extending from 2008 to 2011 and 2012 to 2015 respectively. Amongst these was the Pay Reforms designed to address the problem of low pay and associated performance problems the civil 
service. However, some critics have argued that the whole exercise though good, but fell short of expectations. There is a serious concern whether the costly pay reforms implemented by the Gambian civil service brought any source of motivation leading to enhanced performance of the employees, given absence of research evidence other than official reports. Gambian civil servants remain one of the lowest paid in SubSaharan Africa, with one of the poorest pay scale, which is lowest amongst countries with low income level - this is despite the comprehensive reforms implemented by the government[7]. Further, reports on the challenges of the civil service in 2007 continue to reveal that low pay in the civil service is associated with attrition especially at professional level, low staff morale, indiscipline and corruption[7]. The purpose of this study was to identify the factors that influenced in Gambia's civil service performance levels and establish the extent to which the Gambia's pay reforms enhanced performance and motivation in the civil service of the Gambia. The results of the research are generally applicable and useful to policy makers so as to get better equipped in their engagement with trade unions as well as areas that the government needs to prioritise when implementing evidence based salary reforms in the civil service.

Overview of the Gambia civil service performance and employee Pay satisfaction

The civil service of the Gambia has its traits emanating from the imperialist British colonial administration up until the country attained its independence in 1965[8][9], then the indigenized Gambian civil service took over. The composition of civil service of the Gambia emerges a bloated sector with social services accounting for almost half of entire civil service staff. Education constitutes about 40 percent of the civil service workforce followed by Health constituting 20 percent of civil service staff. The nation's economic services including agriculture employ just about 6 percent of the civil service workforce[10]. The Gambian civil service had a total staff population of 41,958 as of May 2017 with an annual growth rate of about 14 percent [11].

Gambia's civil service pay grades comprise of 13 levels and has a narrow pay grading structure, where salary increment is determined annually through grade point adjustment and employees advance on the career ladder on promotion based on long service rather than out of performance evaluation[7]. The civil service pay policy came into effect from 1991 and cherish on efficiency in recruitment, retention and motivation of quality staff for better management of human and material resources. However, the policy outcomes indicate that the policy has not reached the aspirations for the civil service whose salary benefits remain low compared to the private sector[6].

The Gambia's civil service has been in the past decades using the integrated grading system for its employees. The pay raise was implemented during pay reforms 2008 - 2015,job evaluation conducted purposely targeted removing duplication of duties and outlining commensurate pay grades for every category of work group, particularly the professional cohort but being mindful of the wage bill financial implications[7]. The above factors had been identified in the past, as one of the root causes of inefficiency in the civil service. However, even with the reforms, the grading system is still egalitarian, highly compressed and bundled employees within close salary range regardless of individual job responsibilities involved. Decisions on rewards for employees have been attributed to politicians' influence and not on professional advice [7].

Amongst the predominant pay structure challenges in the Gambia civil service, annual salary increments per grade calculated in percentage terms offered for each pay scale are themselves too low. There are now a large number of allowances paid to different levels and none of them excluding for a long service allowance, are pensionable. The current allowance arrangements present no clear and direct relationship between the grade of a job and what the employee receives as the total package. Low pay level contributes to high levels of attrition within the civil service particularly for professional and managerial. The real value of salary declines annually due to inflation.

\section{THEORETICAL FRAMEWORK}

Many methods have been utilized in studying pay systems in various settings. The study guided by the Pay Satisfaction Questionnaire Method, developed a conceptual framework to help in understanding the determinants of pay satisfaction as well as how pay reforms influence satisfaction and performance of employees. The study also used the Maslow's Hierarchy of Needs framework to review motivation of employees in an occupational setup, and Adam's Equity theory in understanding the gaps. 


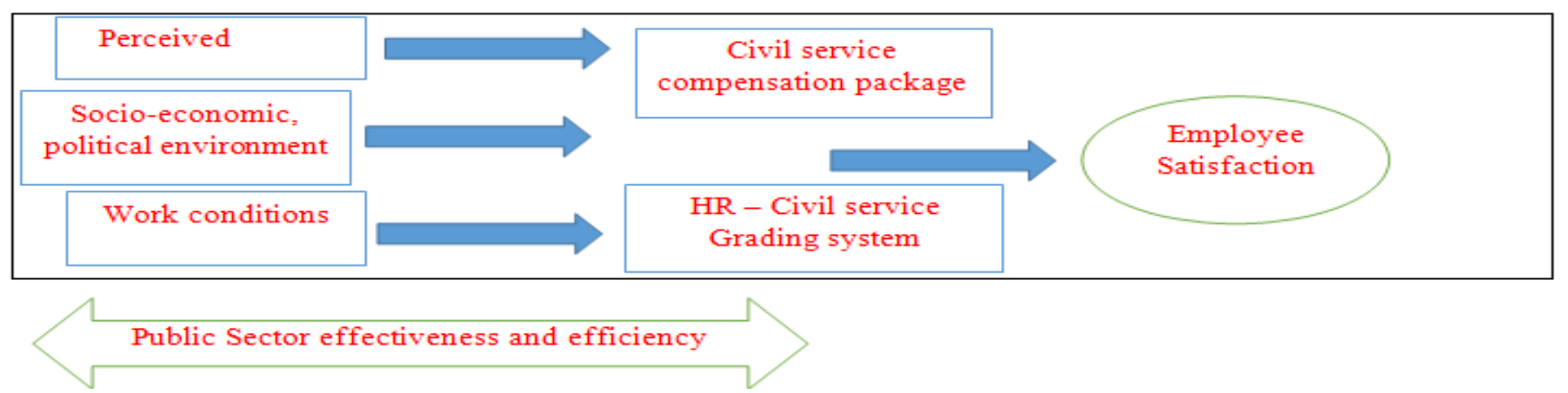

Figure 1 Study Theoretical Framework

There is a missing link in the whole equation where assumptions that pay system tend to motivate employees and positively influence satisfaction. The opposite might be true hence needs to be tested. The Pay Reforms does not state clearly the incentives attached to good performance and attributes of poor performance, hence the researchers present a prospect to assess which factors can explain dissatisfaction concerning compensation framework. The ineffective pay reforms have thus led to the mass exodus of dissatisfied employees resulting in loss of talented workforce leaving the civil sector at the mercy of average or non- performers. Campbell et al.[12] defined motivation as a process that voluntarily derives the individual to produce above desired effort in the expected work assignment. Despite extensive views and theories on motivation, there seem to be lack of consensus on conclusions. Adam's Equity theory theorize that employees in an organization seek to maintain equity between the work input they bring into a job; in form of education, time, experience, commitment, effort and the outcome received in form of promotion, recognition and increased pay, against the efforts from other employees[13]. The equity theory suggests individuals who perceive themselves as either under-rewarded or over-rewarded are likely to experience distress thus, may automatically lead to re-establish equity in the organization. In [14]arguments, organizations tend to fail to solve the problem of equity and then employees may start behaving negatively through either quitting the job or staying. When dissatisfied employees stay within the organization, they are likely to react by withholding effort in order to restrict expected work output or lower product quality, or sabotage the equipment[15]. An under rewarded worker will show a feeling of hostility to the organization and perhaps influence other workers and that may lead to reduced productivity[16]specifically when high performing employees are involved.

There are quite a number of incentive theories regarding pay satisfaction including the Maslow's theory, Herzberg's twofactor theory and Vroom's Expectancy theory, among others[17]. Herzberg two-factor theory cited in [18]reflects organization founded motivational variables as responsible for ultimate employees' job satisfaction. Herzberg's two-factor theory states motivation of employee emanates from job content, its nature, and the tasks performed on job [18]. Therefore, the theory pose that these central characteristics of the job need to be enriched to make it more motivational, especially those employees with higher order needs. The theory explains motivation and employee satisfaction in organizations as driven by corresponding motivation and hygiene factors. Herzberg thus maintains that removing the dissatisfaction hygiene factors would not result in a state of satisfaction; instead, it would result to a neutral state. Therefore, satisfaction and motivation would only occur because of achieving motivation from intrinsic variables.

Abraham Maslow's hierarchy of needs theory also described employees' intent to be committed to an organization. According to Maslow as cited in[19], people are motivated as they satisfy the five hierarchical order of needs namely psychological, security and safety, social, esteem and selfactualization -occurring in form of a hierarchy, ascending from the lowest order to the highest rank of self-actualisation. Thus concludes employee is highly motivated when he moves higher in rank of attaining the needs. Therefore, employers need to understand what type of satisfying needs of the employees need to be satisfied to keep them highly motivated and performing. Maslow's need theory displays logic hence can be beneficial if carefully implemented in the public sector settings. Vroom's expectancy theory demonstrates employee motivation as utility- maximization approach calculated through set motivation formula that incorporates values (valences), self-efficacy (expectancy) and instrumentalities, which are the organizational outcomes[20]. The expectancy theory has some predictive power although it demands more accuracy for organizations to get meaning. Whenever employees find high level enriching job characteristics, they are likely to experience effectiveness given psychological states that eventually induce high levels of employee satisfaction and performance[21],[22].

Jacques and Roussel[23]sampled employees using expectancy theoretical framework in France to study how total compensation elements are likely to influence motivation and job satisfaction. The study concluded that under certain conditions, customized compensation of exempt workers could be a central actor to motivation; flexible pay of nonexempt employees motivates nor rises job satisfaction; benefits of exempt and non-exempt employees do not have anything to with job satisfaction[23]. In the same subject, [24]states incentive compensation encourages enough 
employees to exert their full capabilities in the organisation. The use of money as proxy indicator of motivation has generated a lot of debate from scholars. Kinnear and Sutherland [25] uphold that organizations ought not to be deceived thinking money no longer matters in retaining employees, as it remains an important underlying factor in motivating quality employees[26].A number of studies discussed found an association between rewards and performance. One of the fundamental indicators of assessing effective pay reform of an institution is to gauge pay satisfaction. If employees are satisfied with the pay offered to them, they tend to be motivated to work harder and yield more revenue output for the organisation. Contrariwise if the employees are not satisfied with their pay, they would not work hard neither contribute as such to the organization[27]. Therefore, employee pay satisfaction, work attitude and performance are dependent on each other[28].

As defined by [29] pay satisfaction is the level of positive or negative feelings that individuals have towards their pay and measured by use of a pay satisfaction questionnaire. The person's craving to join a certain organization and to endure with that organization, and thus increase work effort is largely function of the design and execution of compensation scheme[30]. Research bodies have proven that if the perceptions about pay were equal, then a worker would automatically experience pay satisfaction[31]. Existing literature consistently proved that there exists a positive relationship between pay level and pay satisfaction[32]thus giving the researchers an opportunity to use pay to explain and forecast pay satisfaction. Using an abridged scale of measuring motivation within civil service, [33] established there exists a positive relationship between performance and public service motivation. Thierry's theory of pay linked pay changes to individual's personality or self-esteem in organization and thus contend on pay as meaningful given that it reflects individual's relative position and significant dimensions of work[34].

Mukandala and Kiragu[35] observed low salary paid in the public sector is the main preventive factor to the attraction of highly qualified and motivated professionals within the managerial ranks. In Gambia, [11]confirms declining salary levels in the Gambia's civil service, have resulted in high attrition of competent and skilled employees to high-paying jobs in the private sector. In [37] salary can function not only as a motivator, but also used as an instrument for encouraging retention of employee. If not carefully managed, poor remuneration can accelerate brain drain where the organization will lose highly skilled calibre workers to other organisations offering good pay[1].

Schwab and Heneman developed the Pay Satisfaction Questionnaire (PSQ) as a method that can be used to measure pay satisfaction by organizations based on a number of assumptions[32]. In their PSQ, they suggested pay satisfaction occurs mainly on four independent variables namely; pay level, pay structure or pay administration, pay raise and the benefits. However, in-depth studies exposed that pay structure and pay administration may mean the same effects. The advance of the PSQ in studying pay satisfaction led to conclusions from many scholars that pay satisfaction was a multidimensional theory[38] that has dissimilar features and outcomes[39].A Study by Padmakumar Ram and Gantasala V. Prabhakar in the hotel industry in Jordan also professed hypothetically pay satisfaction is multi-dimensional, as they measured it using the Pay Satisfaction Questionnaire[32]. The study results presented that all factor loadings for the four dimensions of pay satisfaction namely for Pay-raise, Benefits, Structure/Administration and Pay level were strong.

In the writing of [35] most governments in Africa meet challenges to remunerate adequately their workforce for purposes of meeting their basic living expenditure as remuneration packages are extremely low resulting in institutional corruption, negligence and lack of discipline. Rijckegham and Weder as cited in[35], offer evidence in their study of 31 countries that correlation exists between civil service pay and corruption. In their study conclusion suggests vigorous wage policy can be effective in dealing with manifestation of corruption. According to [35], Tanzania's 1997 Presidential Commission of Enquiry on Anti- corruption Report, stressed the connection between termed petit corruption and low civil service salary. Therefore, in Gambia, there is likelihood that low salaries are one of the key factors that have permitted the rise of indiscipline and unethical conduct within the civil service employees. A pay system is one of the most practicable and central factors to motivate the employees[1]. An indication that if employees are motivated, means they are satisfied. They emphasized workers work attitude directly affects their daily performance in an organization and the level of pay satisfaction directly affect the working attitude of that employee. The effects therefore give an indication of the importance and relevance of the employee's pay satisfaction or otherwise can point to the success or failure of that respective organization. When incentive compensation is thus guaranteed, staff basic living standard inspires employees to assume a high degree of commitment to exert their full competences in the organization. Finally, [32]proved that pay satisfaction is strongly associated to the attitude of employees such as work attendance, turnover and union vote thus the recorded attitude can be used to measure effectiveness of the organization's compensation programmes and policies.

\section{Empirical Studies on Salary Reforms}

Many African nations generally share similar challenges about civil service compensation reforms. The country experiences were limited to financial incentives in motivating workforce and general determinants of pay satisfaction. In [36] an overall decline in salary levels in most African nations in the period 1990s to 2001 was largely attributed to the on-going reform challenges and efforts to reduce the size of the wage bills for the civil service. However, the note can be criticised as African regions present the sectors expected to utilize less, 
as there is less proportion of workers to what civil service governments actually spend. Donor support is sometimes essential in pioneering pay reforms in many African countries. In Tanzanian civil service, pay reforms were implemented through a well-designed performance-oriented salary enhancement scheme aimed at improving public sector performance specifically anticipating eradicating related problems like corruption, high attrition among other issues[35],[36].According to[41], the Tanzania's Selected Accelerated Salary Enhancement (SASE) arrangement carries one of the main objectives of adjusting salaries to be a sustainable motivation for public officials [42]. Many authors perceived the SASE scheme as a progressive reform, which well adapted to the Tanzanian setting, reinforced, and rooted bureaucratic values such as transparency and excellent performance. Rugumyamheto[43]contends that incentives for civil servants created a momentum for increased performance in Tanzania, public expectations were raised and the external demands for accountability and efficiency were also raised.

South Africa in dealing with effects of the apartheid era emerging from the black majority rule in 1994, adopted a systematic and continuous civil service reform particularly invested their effort in improving civil service pay. Pay reform process commenced in 1997 with a 'White Paper on Human Resource Management' in the civil service[44].In April 2003, saw the introduction of South Africa's Incentive Policy Framework that linked the progression of pay to employee performance appraisals in the Public Service[45]. The most important aspect noted from the reform was the involvement of senior managers in leading performance monitoring and evaluation. Nigeria under the civilian governance of the retired President Obasanjoin 1999, adopted reforms to revitalize the public service dealing with compensation agenda in the public sector that had declined over time when measured against inflation compared to private sector performance. The reforms targeted on downsizing the public service i.e. removal of about 33,000 employees from the federal public service states[46]. The Nigerian government implemented payr eforms contingent on the target period of 2008, which was the political term of office of the government. Notably, some of the civil service reforms in many African countries could not be implemented by 2008, but they remain noted as essential for the reformation process for the entire African countries[47][48].

\section{METHODS AND MATERIALS}

\section{Population and Sampling}

The study focused on civil sector concentrating in the capital city of the Gambia Banjul. Other regions and districts could not be included in this study due to resource constraints. Key informants interviewed were also exclusively limited to those cadres within urban centers given challenges associated with communication in the regions. The study, applied purposive sampling technique in deciding the sample. The study used a target population of 250 civil servants selected purposefully from different government ministries in Banjulthe capital city. The rational for this choice is that Banjul is the administrative city of the Gambia where many ministries and their line departments are located. So many civil servants commute to work in Banjul daily and this covers all categories of workers. In identifying the sample, the study selected five main ministries that deal with essential services in the country with a strong belief that the target ministries are affected when there is low motivation and performance amongst its employees. The sampling frame also restricted the study to top permanently employed employees who completed their probation. However, it was not possible to limit the sample to age groups hence all members of the civil service had a chance of getting into selection despite of their age. The sample is capable of representing the larger population views given that most of civil servants targeted actually come from different ministries and line departments.

\section{Data collection Methods}

The study used both primary and secondary data collection techniques. This study conducted a survey and collected primary data from sample of 250 respondents within Gambia's civil service using the customized Pay Satisfaction Questionnaire (PSQ) method by [32]widely used in many researches to assess; the dimensions of satisfaction within areas; pay administration, pay raise, motivation, attrition, and attitudes outcome indiscipline as a response to implemented pay reforms. A questionnaire was used for data collection with structured questions, which guided respondents on satisfaction indices within the context of the Gambian civil service. The questionnaire had closed questions measured on developed rating scale used to measure opinions, reactions and attitudes of the respondents. The questionnaire was pilot pretested on twenty participants before its final use for data collection and adjusted accordingly. The purpose of pretesting was to identify possible problems in the questionnaire and allow the researchers to revise the instrument before the actual study. Further, experience and observations were made to verify study results based on the researcher's time spent serving as a staff member in the Office of the Personnel Management of the Gambian civil service.

In examining policy effectiveness, the study reviewed secondary data mainly comprising of official policy documents on the personnel of the Government of Gambia. The research reviewed and analyzed existing articles, reports and lots of published research papers related to the topic under study. More than 35 publications and articles on pay satisfaction were reviewed to get country experiences and define an appropriate method for collecting data. Interviews were used to verify some of the perceptions and policy issues on pay reforms amongst selected key informants based on the prepared interview guide.

\section{Data presentation and analysis}

Descriptive statistics, research response narrations were used to analyze the data from excel sheets, firstly on the 
demographics, policy effect (motivation, living standard, attrition, indiscipline), and employee satisfaction or dissatisfaction with pay reforms. The research questions were analyzed using excel spread sheets to get frequency distributions and percentages and presented in form of graphs, charts and tables. Descriptive explanations based on observations made by the researcher at work also guided the process of coming up with findings and conclusions.

\section{RESULTS AND DISCUSSION}

The study aimed at assessing the effects of pay reforms in influencing satisfaction and performance levels within the Gambian civil servants following the effected pay reforms in 2008-2015. From target $n=250$ respondents, the response rate was $79 \%$. The study grouped respondents according to their gender, age and their level of education to give suggestive information in relation to satisfaction levels in the civil service of Gambia. Of the respondents who participated in the study, $69 \%$ were males and $31 \%$ were females thus suggestive of the perception on satisfaction aspect on pay system of Gambia as largely influenced by gender aspect. Literacy levels for women in the Gambia stood at $40 \%$ as at 2013 thus remain as a barrier to women's economic and social empowerment pivotal for a balanced society[49].The distribution also suggests that dissatisfaction recorded in Gambia's civil service has high prospects of being influenced by unequal employment opportunities for women largely stemming from the pay policies. The existing Pay Reforms in Gambia pioneered from 2008 might have ignored the concept of gender balance hence concentrated more on differentiating figures between pay scales thus leading to possible dissatisfaction of the women constituted departments and sections within the civil service. The existing imbalance suggested by the study results actually confirms the assertion by [49] that Gambia is a patriarchal society and observes cultures that obviously affects negatively on women in the Gambia in many ways.

The study also analyzed the sample by age groups to understand the possible concentration of satisfaction or dissatisfaction levels within the civil sector.

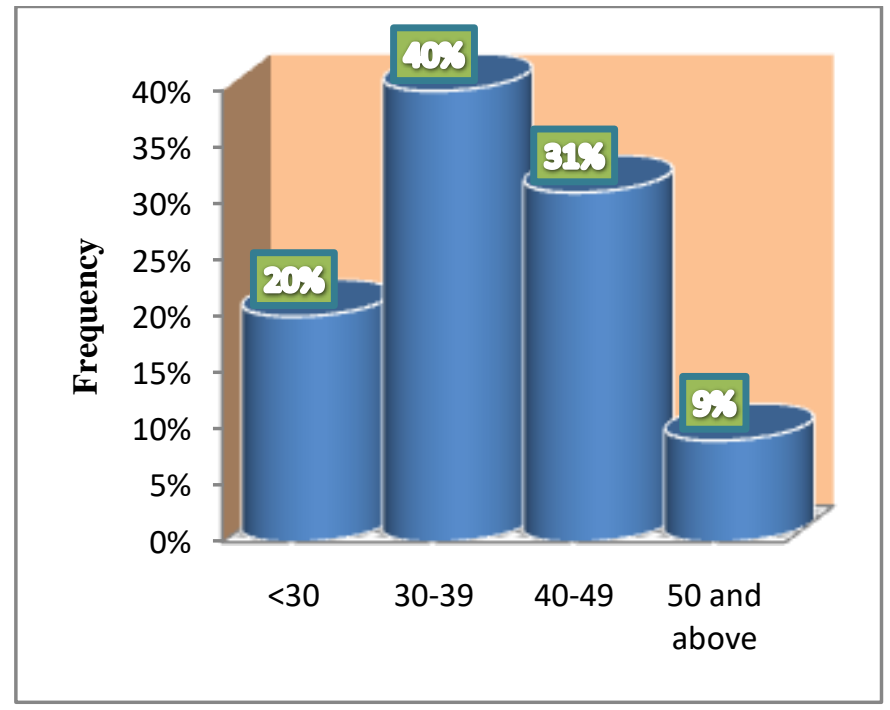

Figure 2 Distribution of Respondent by Age

The majority of civil service workforce seems to be between the age group of 30> and 39 constituting 40\%. This study unveils that $9 \%$ of staff are in their age of $>50$ and above thus suggestive that these are likely to be satisfied with prevailing salary scales as they have high chances to lose or benefit less from pension gratuities and contributions should they decide to leave civil service before the $60^{\text {th }}$ birthday. Usually, high satisfaction levels tend to be associated with those above the economically active group thus they constitute of fair work performers. The age structure of the civil service - consisting of many youth, reflects the general youth population structure of the Gambia with approximately $60 \%$ under the age of $<35$ years [49], thus compete to get into service, as unemployment standing at 35.3 per cent[50], The distribution and suggestion coincide with[51], views that the employers stand to benefit by engaging young workforce and this has gained recognition among academics, government agencies and businesses globally. In relation to the Maslow's Hierarchy of Needs Theory of motivation, there seem to be high likelihood of uncertainties and dissatisfaction levels within the youthful given the uncompetitive pay structure of the Gambia civil sector. The personnel records of Gambia civil service indicates, annual average attrition rate of the professionals rose from 5\% to $7.5 \%$ in 2014[11].This is an indication that efforts should be redoubled by the government and development partners to scale down youth unemployment in the country. The respond's education profile was analyzed as below. 


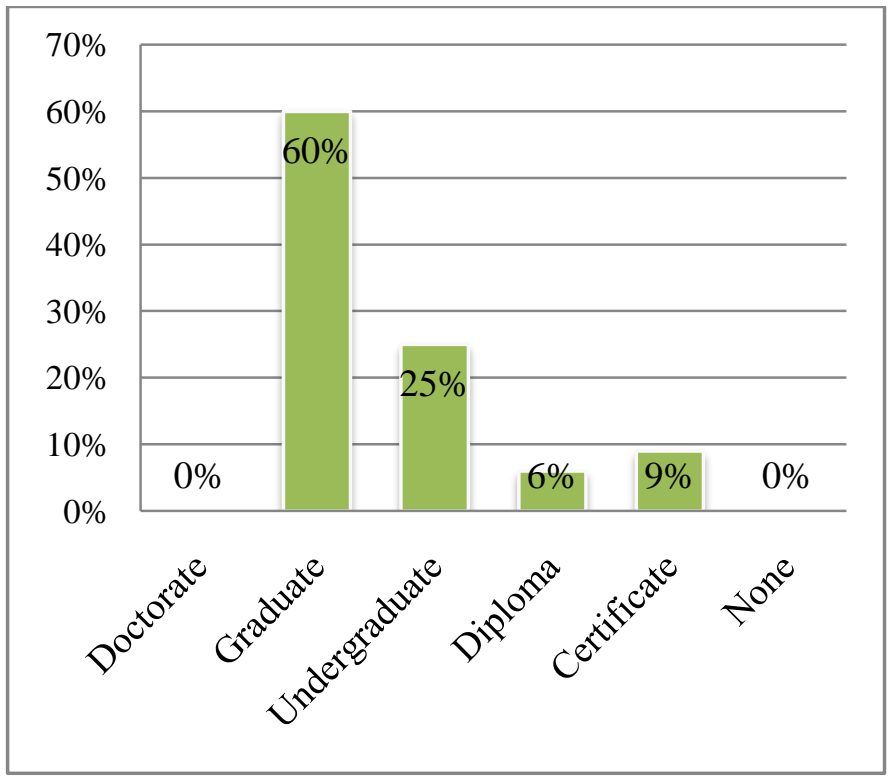

Figure 3 Respondents Education level

Figure 3, revealed the majority of the respondents were graduates, which took $60 \%$ of the $n=250$ sample and the undergraduates with $25 \%$. The distribution reflects that most of the Gambia's civil service is concentrated in one band of professions hence might confirm the pay structure that seem have bundled professional within few middle grades. The Gambian civil service currently uses the caste lion grading system to determine salary scales for employees thus suggestive that the majority are bundled within closely arranged grades which could be a source of dissatisfaction. The data gathered also reflects that Gambia's civil is highly professionalized which exerts pressure on the Government's pay structure as this constitute the economically active group that is still highly competitive to get high paying jobs. There are high chances that those who can be easily satisfied with pay scales are those not highly educated (Diploma and certificate holders) as they are likely getting satisfied with current jobs, they are permanent and would not prefer continuously seeking alternative jobs. This group could yield high satisfaction levels and perform satisfactory within the civil service. Unfortunately, they constitute the minority of the population (15\%) as suggested by the study results. Given that the civil service pay scale is not attractive enough to compete for professionals within the job market [6], there are high chances that dissatisfaction levels within Gambian civil service are at peak as the pay reform struggles to retain the qualified and skilled professionals within the civil sector. The high concentration of the educated workforce is an indication that much policy attention is required on capacity development and training opportunities as an operational strength for the civil service[11].

In understanding the Gambia civil service performance levels, it was essential to master the distribution of grades within the workforce as well the length of service of those giving views about levels of satisfaction of dissatisfaction.

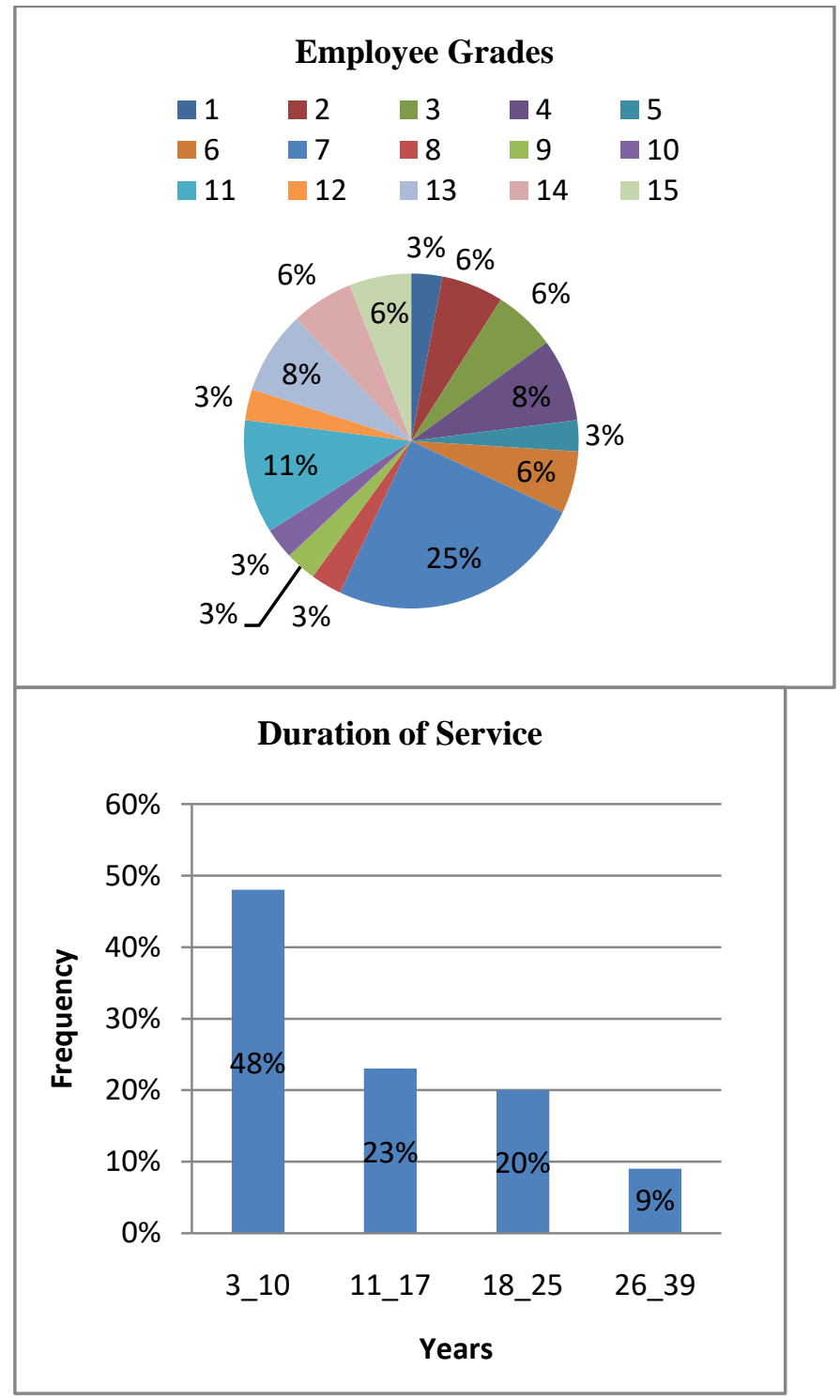

Figure 3 Employee Grades and service duration

According to Figure4, the majority of the staff grades in the category are in grades7 with (25\%). The Grade 10,11 and 12 reflect a large concentration of workforce. Precisely almost half of the employees sampled in the civil service only served for 3 to 10 years indicating they are new into employment sector hence their satisfaction rank might still be basic in reference to Maslow's Hierarchy Motivation framework. World Bank[6] on Gambia supports the statistical finding by confirming the argument that attrition is high in the civil service. One of the reasons for limited capacity in the civil service at many government institutions is that many civil servants and well trained for that matter, abandon the government sector for other jobs that are more rewarding[7]. Therefore, performance levels of the Gambia's civil service are grossly affected by the manifested attrition characterizing the inexperienced civil service of Gambia. 
The study established the main determinants of poor performance amongst the respondents who participated in the study and the distribution was as in Figure 5.

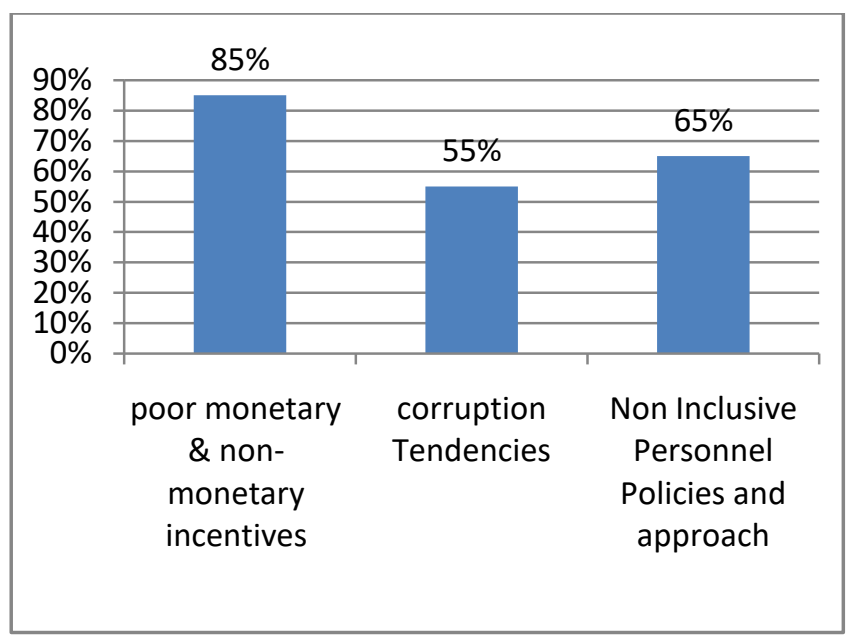

Figure 4 Percentage Distribution on the causes of poor performance in the Gambia

Respondents gave their views on what they feel from selected determinants of poor performance amongst civil sector agencies and or departments within the period $2008-2015$. As in Figure 5, eighty-five percent (85\%) of respondents indicated poor pay reforms or system was the root cause of poor performance, whilst $55 \%$ were of the view that corruption was the seed of poor performance in the Gambian civil service. The study therefore, believed corruption tendencies are a reflection of a decaying state of ethics amongst largely pushed by low remuneration offered by the civil sector. To support further this belief, the distribution from the study confirms the trend from the Gambia Personnel Discipline Records[11]where there was an increase of discipline cases on corruption from average 12 per quarter before 2008 to 26 cases by 2014 .

Interviews confirmed, mostly of the petty corruption experienced and the abuse of the public office by the members of the civil service is done in a bid to supplement their merger wages. McCourt [53] support the above assessment by suggesting the correlation between the level of civil servants salaries and the corruption is a strong one in that government workers grossly underpaid, mostly depend on small kickbacks from the public to supplement salaries and feed their families. However, all the interviewees agreed that squandering government money is one of the biggest problems and attitudes need to change for the Gambia civil servants, but still petty corruption is habitually a survival strategy.

The non-inclusiveness of pay reforms and approaches led by the personnel department came out as one of the contributors of employee dissatisfaction $(65 \%)$ thus yield to low motivation levels amongst Gambia's civil service workforce. Although this assumption requires further assessing using experimental studies, the conclusions help us to understand the limitations that currently characterize the Personnel Pay policies and programmes in Gambia's civil service. In analyzing the scope and magnitude of participation of Gambia civil service in policy development on reward and compensation system following pay reforms 2008-2015 the study revealed the following.

Table 1 Frequencies on Staff participation in Policy formulation

\begin{tabular}{|c|c|c|c|c|}
\hline & $\begin{array}{c}\text { Strongly } \\
\text { Agree }\end{array}$ & Agree & $\begin{array}{c}\text { Strongly } \\
\text { Disagree }\end{array}$ & Disagree \\
\hline $\begin{array}{c}\text { Were the Staff consulted } \\
\text { on pay decision during } \\
\text { the pay reforms 2008- } \\
2015 .\end{array}$ & $8.57 \%$ & $8.57 \%$ & $45.72 \%$ & $37.14 \%$ \\
\hline $\begin{array}{c}\text { Is it important to consult } \\
\text { the staff on pay decision } \\
\text { making? }\end{array}$ & $51.43 \%$ & $40.00 \%$ & - & $8.57 \%$ \\
\hline
\end{tabular}

Table 1shows, of the respondents few (9\%) agreed and9\% strongly agreed that they were consulted on pay decisions during the pay reforms of 2008-2015, nearly half of the respondents disagreed (37\%) and (46\%) strongly disagreed. This data is reflective that most of the civil servants were not consulted and suggestive they do not have much say into the development and implementation of the pay reforms. Therefore, there is high probability that dissatisfaction levels are high and motivation is low amongst the civil service due to non-inclusivity in the reform agenda hence supporting the theory that performance tends to be low when motivation is also low[32].

The majority of respondents agreed (40\%) and 51\%strongly agreed it is important to let the staff participate in pay policy formulation. Few respondents disagreed (9\%) and none strongly disagreed. The distribution indicates most of the civil servants acknowledge the importance and relevance of their involvement, in deciding their motivational packages when it comes to pay. The study by[54]concludes that allowing employees to participate in the reform process helps to attain procedural equity and thus advance pay satisfaction. They suggest that managers must use professional reliability when conducting job evaluation or analysis, designing compensation benefits or any pay related tasks, in order to achieve equity and justice. The employees need to have access to results and any evaluations processes conducted and in that way, employees would feel fair and more motivated to perform. This goes to say that once the employees are engaged in pay reforms; they may easily identify themselves with such initiatives and would appreciate or most possibly take ownership of the outcome. A study conducted by[11], reveals if there was commitment to implementation of reforms phase II 2012 - 2015 in the civil service and beyond the institutional level of Personnel Management Office, there would be far much higher levels of satisfaction and performance of civil sector recorded. The only way to explain these serious gaps in the implementation process is absence of sense of ownership and commitment to participate and support the programme due to no involvement of subjects in the process. 
In a survey by [35] in collaboration with [11] conducted for the Gambia civil servants on their involvement and participation in the Pay Reform, the survey results revealed majority of senior officers (57\%) are aware of the primary goals and objectives of reform programme. Their study further points out that the ineffective implementation of the Civil Service Reform Implementation Governance Framework highlights the disintegration and non-involvement of key stakeholders in discussing and requisite commitment for implementation of the reforms[11]. Also [55]suggests that the effective implementation of any policy reform entail building strong partnerships and consensus in the civil sector and depending on staunch converts of the reforms agenda in key management and administrative positions. He adds that creation of partnerships within various stakeholders including civil service leadership and entire workforce is a precondition for fruitful application of sustainable reform agenda thus realized through participation and engagement.

The study analyzed the employee satisfaction in the civil service assessing policy effects using variables; motivation, living standard, attrition and indiscipline. Table 2 outlines analysis of data collected from the respondents.

Table 2: Policy Effects of Employee satisfaction and Performance

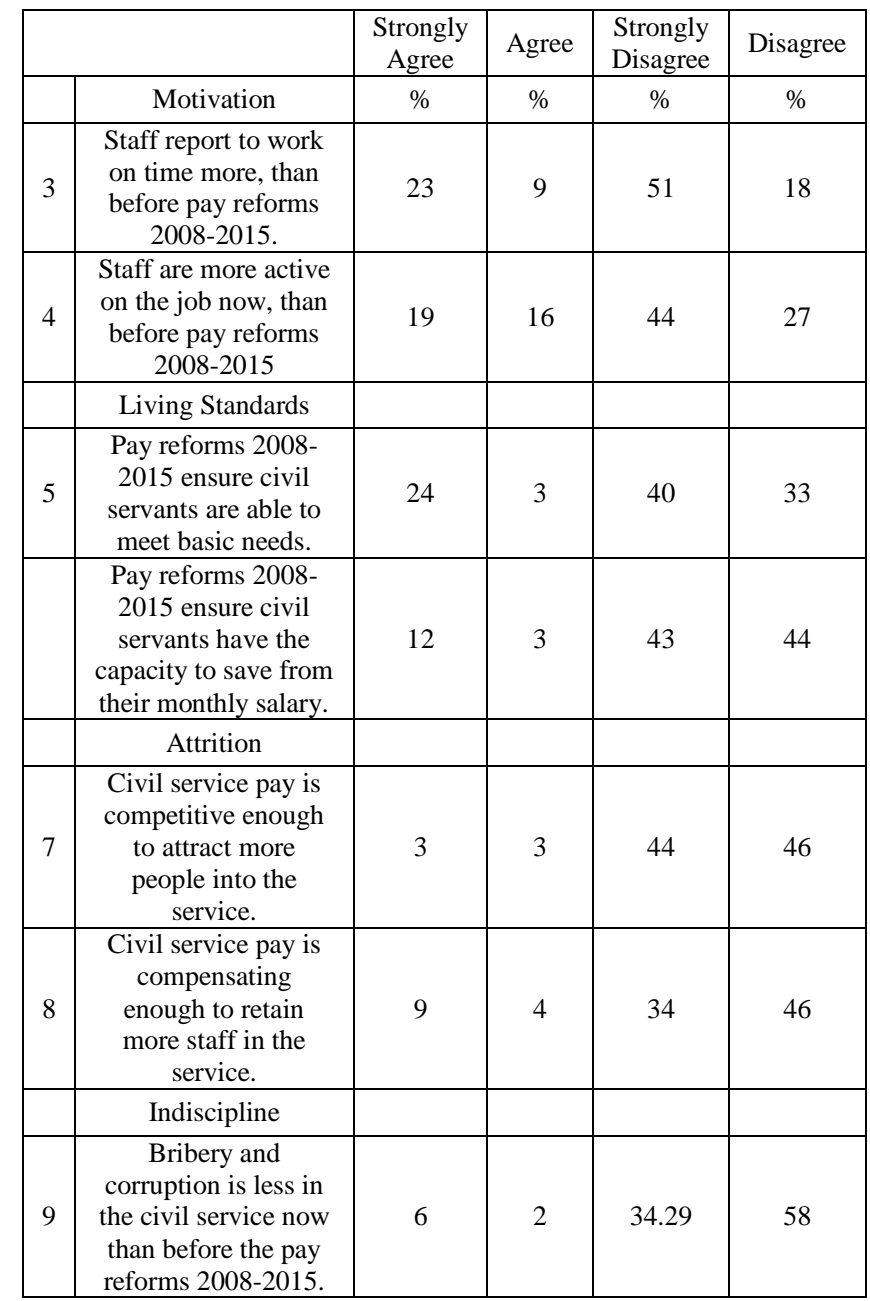

Table 2 shows, from the sample, about a fifth strongly agreed that staff report to work on time more following the pay reforms, nearly a fifth of respondents disagreed and about half strongly disagreed.The study thus reflects that the pay reforms 2008-2015, might not be well motivatingfor civil service while using panctuality at work as a proxy to satisfaction. The salary and grading structure, is not stimulating adequate staff motivation, responsibility, compensation for competence and distinctive career progression [11]. The argument by [32]supports that pay saisfaction is closely connected to employeee attitudes and practices incluing panctulaity to work, staff turnover and particpation in union activities. Therefore the ideal situaton would translates that workers if satifiedwith their salary would be loyal and always report on time for work than if they are dissatisfied. Therefore there is substantive evidence to suggest that pay reforms in the Gambia did not bring anticipated satisfaction hence motivation levels and perfomance of civil servants remained low.

The study reveled $58 \%$ of the respondents strongly disagree that bribery and corruption is now less in the civil service than before the Pay Reforms 2008-2015. The result suggests that despite the Gambia's Civil Service Reform Strategy of 2017, civil service reward system has not changed the attitudes and ethics of civil service workforce. Few respondents agreed agreed that workforcehas been more active following the pay reform, nearly a quarter of respondents disagreed (27\%) and nearly half strongly disagreed (44\%). The study thus reflect that the workforce in the civil service of the Gambia are not active compared to before the pay reforms, thus leads us to a conclusion that the civil service has not recorded any meaningful motivational status change and anticpated performance levels since pay reforms.

The sudy results indicate, only a few respondents perceive pay reforms ensured civil servants 'now as able to meet the basic needs', 33\% of respondents disagreed with that and the majority strongly disagreed (40\%). The results suggests that most of the civil servants are not able to meet their basic needsfrom their pay following the pay reforms in Gambia. The results actually confirms the theory from Maslow's Hierachy of Needs that indivuals would be motivated once their lower first need is met. Of the sample utilized in the study, only few respondents (3\%) agreed and a handful strongly agreed that 'the pay reforms ensured that civil servants have the capacity to save from their monthly incomes'. Actually quite a good number (43\%) strongly disagreed with that statement. This results gives a probability that the civil servants are not able to have savings from their income suggestive that salaries area source of dissatisfaction. The study also results supports notion that the civil service pay structure is below the local labour market standard and translates that the challenge of attracting competent staff into the servcie remains a big challenge. The results are in agreement with[30]suggestions that an individual's aspiration to get attached to or stay in that organisation, and be effective 
in that organisation is a function of the design and implementation the reward system. Effectiveness in this respective case could be interpreted as motivated.

About $58 \%$ strongly view 'bribery and corruption still rampant less in the civil service than before reforms'. The study results actually confirms [35] claim that low salariestend to give rise to petty corruption such as sale of government services including 'charge-under-the-table dealings', or forcing on payment by government teachers to instruct schoolchildren. The study therefore concludes that pay reforms in Gambia did not reduce corruption tendancies in the civil service when using corruption as a proxiy for satisfaction. There is a strong perception that prevalance of unauthorized absenteeism is now still recorded amid civl service reform objectives to curb such tendancies. Likewise, any system or organization, with insistently low employee remuneration and benefits, ultimately leads to low staff morale, indiscipline and inactiveness thus leading to poor job performance. Therefore, the study concludes Gambia's rewrad system and reforms implemented in 2008 - 2015 could be a source of dissatisfation and poor perfomamnce.

The study assessed the views on effectiveness of Gambia's reward structure and $80 \%$ of the respondents strongly disagreed to the view that 'the reward system in the Gambia Civil Service was effective and motivational' while $15 \%$ disagreed to the opinion. However, $5 \%$ of the respondents agreed along the view thus reflective that the reward reforms implemented did not support performance and satisfaction of civil service. The key informants criticised the civil service reward system upholding that it was characterised by income discrepancies among officers of the same. The researchers also observed that the current grading system bundles all members hence does not stimulate progression of employees. Once employees are dissatisfied, there are high chances of demotivation, which leads to low performance of the civil sector. The current pay structure for the civil service not only has a high number of grades, there is also a little indication of rational span of command within the current cadre grading. The pay arrangement for the civil service indicates high compression of grades. Thus, the study points this as one of the factors of dissatisfaction contributing to high attrition among the professional groups[11]. Generally, civil servants pay, are far below the prevailing National Poverty Datum Line. Such low salaries paid by government become economically unsustainable against a backdrop of an insuperable collection of basic needs. Civil servants emerge overburdened by an unsustainable debts and arrears in the form of rates, electricity and water bills, and accommodation rates amongst many. The breadbasket cost for households fail to be meet with the low salaries paid hence there is great likelihood of dissatisfaction amongst civil service employees. The government pays an incentive to those working in rural parts of the country as an incentive targeting long retention effects. However, the percentage paid for provincial allowance is still far less an incentive compared to opportunities in the urban centers. This low allowance for out posting is a source of dissatisfaction in the civil service. As part of human resources development, all employees are trained in various disciplines using the government grant. The courses are needs driven and are expected to improve on the job performance of the employees. However, the study reviews reveal that the intended benefits are still far from achievement. Years following the pay reforms, reports point that not much difference has been made to the civil service earnings; majority of them can barely sustain themselves with their monthly income and are still in the norm of targeting jobs in the private sector even with small salary differential.

According to[7], the civil service compensation benefits are too little to incentivize the employees to offer best employment effort into the service. The distribution of the prevailing pay benefits confirms that top officials benefit more than the lower grades who only benefit from the paid annual leave and nothing more. The study results are supported by Adam's equity theory, which state that an individual considers being treated fairly if he perceives the ratio of his input and outcome including those around him or shemay be hostile towards colleagues at work, which may result to poor performance [22].

All the intervieweessuggested that there was urgent need by the government of Gambia to relook at the reward system and draw at least a competitive pay structure matching the best practices adopted by other African countries. The Gambia's civil service pay structure reflects employees are too compressed in grades thus does not commensurate the existing workload hence indicative of being source of dissatisfaction amongst the employees.A high pay system, attracts, motivates and retains employees to work for an organization[1] whereas a low pay system often does not attract clients in the labour market, neither motivates existing workers nor commit them to continue work with the organization. The best model could be that of South Africa where most of the public sector employees prefer to stay longer or everyone admires getting into public sector as a greener pasture. The working environment need to develop to enable a climate capable of motivating the Gambia's workforce so that they would be able to meet basic needs as postulated by Maslow in their motivational framework. In general, the respondents agree that pay reform process requires stakeholder involvement to receive feedback from all parties concerned. The Gambia Personnel Management Office need to carry out an independent study to establish the true feelings of the masses on the pay reforms implemented by the Government.

There is need to development of a competitive reward system. Government should as much as possible, narrow public-sector pay differential with that of private sector based on labour market analysis, to improve morale within the service. The human resources management component of there forms is supposed to effectively deal with aspects of rewarding the civil servants and develop competent reward system. The 
question of incentives for the civil servants needs to be debated more seriously beyond political aspirations and thinking. Government should learn from such as Tanzania and South Africa Learning from other countries' experiences Pay Reform experiences so as to adapt. Pay structure should be decompressed to improve relative pay at high level. Government's pay reforms, should not take unitary decisionmaking approach, but rather embrace participatory decision making on matters to do with pay reforms. The authorities responsible for compensation reforms must create a framework to include employees input given that pay related issues are topical aspects for employees. Reform policies require support from all concerned stakeholders and a systematic plan of action implemented in a sustainable manner.

\section{CONCLUSION}

The fit between incentive-specific reforms and the public reform process is therefore, a challenge that needs attention thus effort needs to be devoted to designing incentives aimed at changing the Gambia' civil service attitude and perceptions. The government needs to raise its commitment to solve pay related changes for civil service. The commitment must be pioneered through pay and Incentives policy statements targeting to commit reasonable substantial budgetary support towards improving pay incentives for civil servants. The aspirations could be implemented progressively in a staggering approach over midterm to long term frame learning from best practices in the African public sector perspective.

\section{Ethical Issues}

The study sought permission from the PS PMO Gambia to do the survey before the start of the study and permission was granted. All the research data was treated with strict confidentiality and protection of the integrity of the respondents ensured.

\section{COMPETING INTERESTS}

The authors declare that they have no competing interests.

\section{FUNDING SOURCE}

None

\section{ABOUT THE CORRESPONDING AUTHOR}

Bernard Nkala, (Ph.D.) is a highly motivated and experienced Health Economist with extensive experience in health research, and development policy analysis. He is serving as the Director Performance Improvement and Development in Zimbabwe Public Health sector and a part-time Lecturer in the Department of Economics at Bindura University of Science and Education - Zimbabwe. Dr. Bernard Nkala earned a Ph.D. in Economics majoring in health policy and practice from the National School of Development at Peking University, Beijing in China.

\section{REFERRENCES}

[1] Dae-Bong, K. (2009). Human Capital and Its Measurement. Busan, South Korea: Organization for Economic Cooperation and Development OECD World Forum on Statistics, Knowledge and Policy,KnE Social Sciences / International Conference on Economics

[2] Claudio Lucifora (2015). Performance-related pay and labor productivity: Do pay incentives and financial participation schemes have an effect on a firm's performance?IZA World of Labor. https://wol.iza.org/uploads/articles/152/pdfs/performancerelated-pay-and-labor-productivity.pdf?v=1

[3] George B.N. Ayittey (2018). Applied Economics for Africa, Atlas Network, Arlington, VA 22203, USA

[4] Mark Robinson (2015). From Old Public Administration to the New Public Service Implications for Public Sector: Reform in Developing Countries, UNDP Global Centre for Public ServiceExcellence, Singapore. Online http://www1.worldbank.org/publicsector/Reforming.pdf

[5] World Bank (1993). The East Asian miracle: Economic Growth and Public policyhttp://documents1.worldbank.org/curated/en/975081468244 550798/pdf/multi-page.pdf

[6] World Bank. (2010). The Gambia - Improving Civil Service Performance: Public Service Pensions Policy Reform Note,Volume I: Main Analysis. Onlinehttps://openknowledge.worldbank.org/handle/10986/2849

[7] Public Administration International (2019). Consultancy report;The Gambia - Restructuring of the Pay and Grading System of the Gambian Civil Service 2013 to 2020Online:https://www.public-admin.co.uk/case_studies/test/

[8] Baba G. Jallow(2014). Leadership in Colonial Africa,Palgrave Macmillan, New York

[9] Government of the Gambia Personnel Management Office (July 1993). Wyatt Company Actuaries andConsultants, Report on the Review of the Civil Service Pension Scheme

[10] Government of the Republic of the Gambia (July 2005) National Medium Term Investment Programme

[11] Government of the Gambia Personnel Management Office (2010 2017). Human Resources Management Report Civil Service

[12] Campbell,J P \& Pritchard, R D (1976). "Motivation Theory in Industrial and Organizational Psychology" in M DDunnette [ed] Handbook of Industrial and Organizational Psychology, Chicago,Rand McNally

[13] Richard A. Cosier\& Dan R. Dalton (Apr., 1983). Equity Theory and Time: A Reformulation. The Academy of Management Review, Vol. 8, No. 2, pp. 311-319 Online: https://doi.org/10.2307/257759

[14] Don Hellriegel; et al (2008). Management 3rd Ed. Cape Town; New York: Oxford University Press, South Africa

[15] Burgess, S., \& M. Ratto(2003). "The role of incentives in the public sector: Issues and evidence."Oxford Review of Economic Policy 19:2: 285-300.

[16] Gielen, A., M. Kerkhofs, and J. C. van Ours(2010). "How performance related pay affectsproductivity and employment." Journal of Population Economics 23:1: 291-301

[17] Wang, H., Law, K. S., Hackett, R. D., Wang, D., \& Chen, Z. X. (2005). Leader-Member Exchange as a Mediator of the Relationship between Transformational Leadership and Followers' Performance and Organizational Citizenship Behavior. Academy of Management Journal, 48(3), 420-432.

[18] Herzberg et al (1999). The Motivation to work New York, Wiley

[19] Shadiullah K. Allah,NawazA. Nawaz (2010). Theories of job satisfaction: Global applications \& Limitations.Gomal University Journal of Research, 26(2), 45-62

[20] Vroom, V. H (1964). Work and motivation. New York, Wiley \& Sons.

[21] Prendergast, C.(2008). "Intrinsic motivation and incentives." American Economic Review 98:2:201-205.

[22] Hackman, J. R. (1980). Work redesign and motivation. Professional Psychology, 11(3), 445-455. 
[23] Jacques Igalens\& Patrice Roussel (1999), A Study of the Relationships between Compensation Package, Work Motivation and Job Satisfaction: Journal of Organizational Behavior, (Vol. 20), No. 7 pp. $1003-1025$

[24] Ping Liu, MdSajjadHosain\&Liyan Li (2019). Does the compensation gap between executives and staffs influence future firm performance? The moderating roles of managerial power and overconfidence Online: https://doi.org/10.2478/ijme-2019-0025

[25] Lisa KinnearMargie Sutherl\&Margie Sutherland (2000). Determinants of organisational commitment amongst knowledge workers, South African Journal of Business Management 31(3):106-112

[26] Pritchard, R.D \&Deleo, P.J (1973). "Experimental test of the valence- instrumentality relationship in job performance" Journal of Applied Psychology, 57 (3)

[27] Lazear, E. (2000). "Performance pay and productivity." American Economic Review 90:5: 1346-1361

[28] Martin Fishbein and IcekAjzenIcekAjzen (2010). Predicting and Changing Behavior: The Reasoned Action Approach,Psychology Press

[29] Miceli, M.P., \& Lane, M.C. (1991). Antecedents of pay satisfaction: A review and extension. In G.R. Ferris \& K.M. Rowland (Eds.), Research in personnel and human resources management (Vol. 9, pp. 235-309). Greenwich, CT: JAI Press.

[30] Bergmann, T.J., \& Scarpello, V.G. (2002). Compensation decision making. United States: South-Western Thomson Learning.

[31] Milkovich G.T.; Newman, J.M. (2008). Compensation, (9th Ed.). McGraw Hill International Edition, USA.

[32] Herbert G. Heneman and Donald P. Schwab (1985). Pay Satisfaction: Its multidimensional nature and measurement, Int J of Psychology

[33] Alonso, P., \& Lewis, G. B. (2001). Public service motivation and job performance evidence from the federal sector. The American Review of Public Administration, 31(4), 363-380. Available from: https://www.researchgate.net/publication/313900269_Public_servi ce_motivation

[34] Theirry, H. (2001). The reflection theory on compensation. In M. Erez, U. Kleinbeck, \& H. Theirry (Eds.), Work motivation in the context of a globalizing economy (pp. 149-166). Hove, England: Psychology Press.

[35] Kiragu, K., \& R. Mukandala. (2003). Public Service Pay Reform Tactics, Sequencing, and Politics in Developing Countries: Lessons from Sub-Saharan Africa. Available online at: http://www.worldbank.org/publicsector/civilservice/Mayseminar/P ayReformStudy.pdf.

[36] Kiragu, K. Mukandala, R. and Morin, D. (2005). Reforming pay policy: techniques, sequencing and politics, in Levy and $\mathrm{S}$. Kpundeh (Eds) Building State Capacity in Africa: New Approaches, Emerging Lessons.Washington:WorldBank, pp.109149.

[37] Lum, L., J. Kervin, K. Clark, F. Reid\& W. Sirola. 1998. "Explaining Nursing Turnover Intent: Job Satisfaction, Pay Satisfaction, or Organizational Commitment?" Journal of Organizational Behavior, 19, 305-320

[38] Heneman, H. G. III, \& Judge, T. A. (2000). Compensation attitudes: A review and recommendations for future research. In
S. L. Rynes\& B. Gerhart (Eds.). Compensation inOrganizations: Progress and prospects, San Francisco: Jossey-Bass.

[39] Judge, T.A.(1993). Validity of the dimensions of the pay satisfaction questionnaire: Evidence of differential prediction. Personnel Psychology,46, 331-355.

[40] Jones DC, Kalmi P, Kauhanen A (2010) Teams, incentive pay, and productive efficiency: evidence from a food-processing plant. Industrial Labor Relat Rev 63(4):606-626

[41] Ulleberg, Inge (2009). Incentive structures as a capacity development strategy in public service delivery: A literature review and annotated bibliography on the role of incentives for civil servants within capacity development policies. International Institute for Educational Planning

[42] Peter J. Morgan, Heather Baser, and Denyse Morin (2009). Developing capacity for managing public service reform: The Tanzania experience 2000-2008,Public Administration and Development. Available at https://doi.org/10.1002/pad.553

[43] JA Rugumyamheto(2004). Innovative approaches to reforming public services in Tanzania.Public Administration and Development 24(5):437 - 446

[44] Dennis Yao Dzansi\&Lineo Winifred Dzansi(2010). Understanding the impact of human resource management practices on municipal service delivery inSouth Africa: An organizational justice approach,African Journal of Business Management Vol. 4(6), pp. 995-1005

[45] Levin, R. (2009). 'Transforming the public service to support the development state',Journal of Public Administration, 44(4:1), 943968.

[46] Ukwandu, D.C. \&Ijere, E.S., (2020). 'Public sector reforms and national development: A situational analysis of post-independent Nigeria', Africa's Public Service Delivery and Performance Review 8(1), a354.

[47] Adegoroye G (2006) Public service reform for sustainable development: The Nigerian experience. Keynote Address, Commonwealth Advanced Seminar, Wellington, New Zealand.

[48] Olomola O (ed.) (2009) Strategies and Consequences of Public Service Reforms in Africa.Dakar: CODESRIA

[49] The Gambia Bureau of StatisticsMarch 29, (2019)https://catalog.ihsn.org/catalog/6065\#metadataquestionnaires

[50] The least Developed Country Report for the Gambia (November 2019) Ministry of Trade, Industry, Regional Integration and Employment

[51] Hasluck, C. (2012). Why businesses should recruit young people [online] Briefing paper. February. London: UKCES. Available at:

[52] http://www.ukces.org.uk/assets/ukces/docs/publications/whybusinesses-should-recruit-young-people.pdf

[53] McCourt, W. (2006): Employment and pay reform in development and transition societies, Public Sector reform in developing countries: New York: UNRISD: Palgrave Macmillan.

[54] Muhammad Naseer Akhtar et. al (2018). High-Performance Work System and Employee Performance: The Mediating Roles of Social Exchange and Thriving and the Moderating Effect of Employee Proactive Personality, Asia Pacific Journal of Human Resources 57(4)

[55] Alex Sekwat (2002). Civil Service Reform in Post-Independence Nigeria: Issues and Challenges, Public Administration Quarterly 25(Q)January:498 